\title{
Tingkat keterampilan sosial anak tk kelompok b di gugus II kecamatan berbah sleman Yogyakarta
}

\author{
Yuana Resmasari \\ Pendidikan Guru Pendidikan Anak Usia Dini, FIP, Universitas Negeri Yogyakarta \\ Jalan Colombo No 1 Yogyakarta, Indonesia \\ E-mail: yuana.resmasari2015@student.uny.ac.id
}

\begin{tabular}{ll}
\hline \hline ARTICLE INFO & ABSTRACT \\
\hline \hline Article history: & Penelitian ini bertujuan untuk mengetahui sejauh mana keterampilan sosial \\
Received: $28-04-2020$ & anak TK Kelompok B di Gugus II Kecamatan Berbah, Sleman. Penelitian ini \\
Revised: $10-05-2020$ & fokus pada keterampilan sosial meliputi keterampilan berkomunikasi, \\
Accepted: $20-05-2020$ & menjadi bagian kelompok, kerja sama, kontrol diri, empati dan tanggung \\
& jawab. Penelitian ini merupakan penelitian deskriptif kuantitatif. Subjek \\
& penelitian ini adalah anak usia 5-6 tahun di TK Gugus II Kecataman Berbah \\
Keywords: & berjumlah 93 anak. Teknik pengumpulan data yang digunakan adalah \\
keterampilan sosial, anak & observasi. Instrumen dalam penelitian ini berupa pedoman observasi. Analisis \\
usia 5-6 tahun & data menggunakan teknik analisis deskriptif kuantitatif. Hasil penelitian \\
& menunjukkan bahwa keterampilan sosial anak usia 5-6 tahun di TK Gugus II \\
& Kecataman Berbah, Sleman masuk dalam tingkat yang sangat tinggi karena \\
& mencakup 49 anak dengan persentasenya 53\%; kemudian pada tingkat yang \\
& tinggi berjumlah 30 anak dengan persentasenya 32\%; tingkat sedang \\
& berjumlah 13 anak dengan persentasenya 14\%; tingkat rendah berjumlah 1 \\
& anak dengan persentasenya 1\%; dan tingkat yang sangat rendah berjumlah 0 \\
& anak dengan persentasenya 0\%. Keluarga, lingkungan, dan sekolah memiliki \\
peran penting dalam perolehan keterampilan sosial anak yang sangat tinggi.
\end{tabular}

This research purpose was to know the social skill children at Gugus II Kindergarten, Berbah, Sleman. This research focuses on the social skill include communicating skill, being part of a group, cooperating, self control, empathy, and responsibilities. This was a descriptive-quantitative research. The subjects of this research were 93 studenst of the Group B at Gugus II Kindergarten, Berbah, Sleman. The technic to obtain data was used observation. Instrument in this research was the from guidelines observation. The data was analyzed by descriptive-quantitative technique. The result show the social skill of 5-6 yearsold children at Gugus II Kecamatan Berbah, Sleman was very high because because they included 49 children with a percentage of 53\%; then at a high level there were 30 children with a percentage of $32 \%$; moderate level of 13 children with a percentage of 14\%; low level of 1 children with a percentage of $0 \%$; and a very low level of 0 children with a percentage of $0 \%$. Family, environment, and school play an important role in obtaining very high social skill of children.

\section{PENDAHULUAN}

Pendidikan merupakan suatu proses yang menyediakan lingkungan pembelajaran supaya dapat mengembangkan bakat dan kemampuan seseorang menjadi optimal. Salah satu jenjang pendidikan awal atau dasar yang dianggap penting dan berpengaruh dalam pembentukan watak, karakter, dan kepribadian sejak awal adalah Pendidikan Anak Usia Dini (PAUD). Dalam Undang-undang No 20 Tahun 2003 dijelaskan bahwa, Pendidikan Anak Usia Dini merupakan salah satu upaya pembinaan yang ditujukan pada anak sejak lahir sampai usia 6 tahun yang dilakukan melalui pembinaan rangsangan pendidikan agar anak memiliki kesiapan memasuki pendidikan lebih lanjut. Pembinaan rangsangan pendidikan yang diberikan di PAUD memiliki tujuan untuk mengembangkan kemampuan anak, baik dari aspek perkembangan fisik motorik, kognitif, bahasa, sosial emosional, nilai agama dan moral, serta seni. Perkembangan sosial merupakan salah satu aspek yang sangat penting untuk dikembangkan. Hurlock 
(2011: p 250) mengemukakan bahwa perkembangan sosial merupakan perolehan kemampuan berperilaku yang sesuai dengan tuntutan sosial. Perilaku perkembangan sosial yang dapat dicapai dengan baik akan menjadikan anak memiliki keterampilan sosial.

Lynch dan Simpson (2010: p 2) menyatakan bahwa keterampilan sosial merupakan perilaku yang mendorong interaksi positif berupa tindakan dengan orang lain dan lingkungan yang mencakup menunjukkan empati, partisipasi dalam kegiatan kelompok, kedermawanan, penolong, komunikasi dengan orang lain, bernegosiasi, dan menyelesaikan masalah. Keterampilan sosial dianggap penting karena dapat memengaruhi perkembangan lainnya, seperti perkembangan sosial dan akademik. Pernyataan tersebut diperkuat oleh data yang diperoleh Eleby (2009: p 6) yang menunjukkan bahwa, beberapa siswa yang kurang memiliki kemampuan akademis yang ternyata dipengaruhi oleh tidak dimilikinya keterampilan sosial secara baik.

Terdapat beberapa faktor yang memengaruhi perkembangan keterampilan sosial. Thalib, S.B (2010: p 159) menyebutkan faktor-faktor tersebut diantaranya keluarga, lingkungan, kepribadian, rekreasi, pendidikan, pergaulan dengan lawan jenis, persahabatan dan kemampuan menyesuaikan diri. Diantara faktor-faktor yang memengaruhi, faktor utamanya adalah peran keluarga, termasuk orangtua yang memiliki peran penting dalam pembentukan diri anak dari kecil.

Anak dapat mengenal keterampilan sosial dengan mengamati lingkungansya keluarganya. Selanjutnya anak akan berusaha mengekspresikan sikap yang menentukan diterima atau tidaknya sikap tersebut di depan orangtuanya. Pernyataan tersebut sejalan dengan penekanan Olcer dan Aytar (2014: $\mathrm{p}$ 977) bahwa, semua keterampilan perkembangan individu dimulai pada tingkat interpersonal dan dengan interaksi antara orang tua (atau anggota masyarakat lainnya yang lebih memadai) dan sebagai peran utama pendekatan lingkungan mempertahankan anak, karena sebenarnya prinsip-prinsip dasar diarahkan oleh perangkat yang berbeda dan anak mengatakan bahwa belajar memiliki tipe yang berbeda. Hal itu juga menjadi penelitian Arslan, Saltali, dan Yilmaz (2011) yang meneliti 224 anak yang berusia 6 tahun, menghasilkan data bahwa adanya hubungan yang positif antara keterampilan interpersonal, regulasi emosional, kesiapan sosial, dan keterlibatan keluarga. Keadaan tersebut juga menjadi perhatian bagi penelitian Ambrose (2013: p 30) yang memberi hasil penelitian bahwa sikap ibu yang negatif seperti menentang keinginan anak-anak menyebabkan kesulitan penyesuaian emosi pada anak-anak dan kurangnya keterampilan sosial dasar seperti kerja sama, kontrol diri, percaya diri, mengambil tanggung jawab yang juga dikenal sebagai keterampilan prososial.

Saat ini hampir setiap keluarga menggunakan teknologi gadget, televisi, dan komputer yang memberi dampak pada setiap kehidupan pada keluarga itu sendiri. Berdasarkan temuan Ayouby (2017: p 78) mengenai dampak negatif penggunaan gadget pada keterampilan sosial terwujud pada perilaku anak diantaranya adalah anak cenderung untuk individualis, susah bergaul dan apabila sudah kecanduan akan sulit untuk dikontrol dari pemakaian gadget.

Rendahnya keterampilan sosial anak juga terbukti melalui data temuan dari Reid, Littlefield \& Hammond (2008: p 1-2) bahwa, beberapa anak usia TK menunjukkan masalah internalisasi seperti kecemasan, malu serta menarik diri dari teman sebaya. Selain itu Reid, et.al (2008: p p2) menemukan bahwa, sebagian anak memiliki masalah hubungan antarpribadi termasuk rendahnya keterampilan sosial khususnya cara pemecahan masalah. Adanya permasalahan pada pemecahan masalah juga menjadi temuan Rita Eka Izzaty, Farida Agus Setiawati \& Yulia Ayriza (2017: p 32) terhadap 35 Taman Kanakkanak di Yogyakarta yang berkenaan dengan pemecahan masalah sosial anak. Temuannya yaitu bahwa strategi penyelesaian permasalahan yang merupakan salah satu keterampilan sosial menunjukkan bahwa jumlahnya paling banyak dilakukan anak-anak pada saat berinteraksi adalah strategi yang cenderung negatif atau bersifat agresi, seperti memukul, menendang, menjambak, dan mencubit.

Meski tidak semua anak belum berkembang keterampilan sosialnya, namun perlu diketahui keterampilan sosial mana yang belum berkembang agar dapat ditindaklanjuti stimulasinya. Oleh karena itu, dalam penelitian ini, peneliti ingin mengungkapkan sejauh mana keterampilan sosial yang dimiliki oleh anak Taman Kanak-kanak Kelompok B di Gugus II Kecamatan Berbah, Sleman, Yogyakarta. 


\section{METODE}

Pendidikan merupakan suatu proses yang menyediakan lingkungan pembelajaran supaya dapat mengembangkan bakat dan kemampuan seseorang menjadi optimal. Salah satu jenjang pendidikan awal atau dasar yang dianggap penting dan berpengaruh dalam pembentukan watak, karakter, dan kepribadian sejak awal adalah Pendidikan Anak Usia Dini (PAUD). Dalam Undang-undang No 20 Tahun 2003 dijelaskan bahwa, Pendidikan Anak Usia Dini merupakan salah satu upaya pembinaan yang ditujukan pada anak sejak lahir sampai usia 6 tahun yang dilakukan melalui pembinaan rangsangan pendidikan agar anak memiliki kesiapan memasuki pendidikan lebih lanjut. Pembinaan rangsangan pendidikan yang diberikan di PAUD memiliki tujuan untuk mengembangkan kemampuan anak, baik dari aspek perkembangan fisik motorik, kognitif, bahasa, sosial emosional, nilai agama dan moral, serta seni. Perkembangan sosial merupakan salah satu aspek yang sangat penting untuk dikembangkan. Hurlock (2011: p 250) mengemukakan bahwa perkembangan sosial merupakan perolehan kemampuan berperilaku yang sesuai dengan tuntutan sosial. Perilaku perkembangan sosial yang dapat dicapai dengan baik akan menjadikan anak memiliki keterampilan sosial.

Lynch dan Simpson (2010: p 2) menyatakan bahwa keterampilan sosial merupakan perilaku yang mendorong interaksi positif berupa tindakan dengan orang lain dan lingkungan yang mencakup menunjukkan empati, partisipasi dalam kegiatan kelompok, kedermawanan, penolong, komunikasi dengan orang lain, bernegosiasi, dan menyelesaikan masalah. Keterampilan sosial dianggap penting karena dapat memengaruhi perkembangan lainnya, seperti perkembangan sosial dan akademik. Pernyataan tersebut diperkuat oleh data yang diperoleh Eleby (2009: p 6) yang menunjukkan bahwa, beberapa siswa yang kurang memiliki kemampuan akademis yang ternyata dipengaruhi oleh tidak dimilikinya keterampilan sosial secara baik.

Terdapat beberapa faktor yang memengaruhi perkembangan keterampilan sosial. Syamsul Bachri Thalib (2010: p 159) menyebutkan faktor-faktor tersebut diantaranya keluarga, lingkungan, kepribadian, rekreasi, pendidikan, pergaulan dengan lawan jenis, persahabatan dan kemampuan menyesuaikan diri. Diantara faktor-faktor yang memengaruhi, faktor utamanya adalah peran keluarga, termasuk orangtua yang memiliki peran penting dalam pembentukan diri anak dari kecil.

Anak dapat mengenal keterampilan sosial dengan mengamati lingkungansya keluarganya. Selanjutnya anak akan berusaha mengekspresikan sikap yang menentukan diterima atau tidaknya sikap tersebut di depan orangtuanya. Pernyataan tersebut sejalan dengan penekanan Olcer dan Aytar (2014: p 977) bahwa, semua keterampilan perkembangan individu dimulai pada tingkat interpersonal dan dengan interaksi antara orang tua (atau anggota masyarakat lainnya yang lebih memadai) dan sebagai peran utama pendekatan lingkungan mempertahankan anak, karena sebenarnya prinsip-prinsip dasar diarahkan oleh perangkat yang berbeda dan anak mengatakan bahwa belajar memiliki tipe yang berbeda. Hal itu juga menjadi penelitian Arslan, Saltali, dan Yilmaz (2011: p 1281) yang meneliti 224 anak yang berusia 6 tahun, menghasilkan data bahwa adanya hubungan yang positif antara keterampilan interpersonal, regulasi emosional, kesiapan sosial, dan keterlibatan keluarga. Keadaan tersebut juga menjadi perhatian bagi penelitian Ambrose (2013: p 30) yang memberi hasil penelitian bahwa sikap ibu yang negatif seperti menentang keinginan anak-anak menyebabkan kesulitan penyesuaian emosi pada anak-anak dan kurangnya keterampilan sosial dasar seperti kerja sama, kontrol diri, percaya diri, mengambil tanggung jawab yang juga dikenal sebagai keterampilan prososial. 
Saat ini hampir setiap keluarga menggunakan teknologi gadget, televisi, dan komputer yang memberi dampak pada setiap kehidupan pada keluarga itu sendiri. Berdasarkan temuan Ayouby (2017: p 78) mengenai dampak negatif penggunaan gadget pada keterampilan sosial terwujud pada perilaku anak diantaranya adalah anak cenderung untuk individualis, susah bergaul dan apabila sudah kecanduan akan sulit untuk dikontrol dari pemakaian gadget.

Rendahnya keterampilan sosial anak juga terbukti melalui data temuan dari Reid, Littlefield \& Hammond (2008: p 1-2) bahwa, beberapa anak usia TK menunjukkan masalah internalisasi seperti kecemasan, malu serta menarik diri dari teman sebaya. Selain itu Reid, et.al (2008: p 2) menemukan bahwa, sebagian anak memiliki masalah hubungan antarpribadi termasuk rendahnya keterampilan sosial khususnya cara pemecahan masalah. Adanya permasalahan pada pemecahan masalah juga menjadi temuan Izzaty, Setiawati \& Ayriza (2017: p 32) terhadap 35 Taman Kanak-kanak di Yogyakarta yang berkenaan dengan pemecahan masalah sosial anak. Temuannya yaitu bahwa strategi penyelesaian permasalahan yang merupakan salah satu keterampilan sosial menunjukkan bahwa jumlahnya paling banyak dilakukan anak-anak pada saat berinteraksi adalah strategi yang cenderung negatif atau bersifat agresi, seperti memukul, menendang, menjambak, dan mencubit.

Meski tidak semua anak belum berkembang keterampilan sosialnya, namun perlu diketahui keterampilan sosial mana yang belum berkembang agar dapat ditindaklanjuti stimulasinya. Oleh karena itu, dalam penelitian ini, peneliti ingin mengungkapkan sejauhmana keterampilan sosial yang dimiliki oleh anak Taman Kanak-kanak Kelompok B di Gugus II Kecamatan Berbah, Sleman, Yogyakarta.

\section{HASIL DAN PEMBAHASAN}

\section{Hasil}

Perolehan skor yang diolah adalah total skor tiga kali pengambilan data kemudian dibagi tiga. Skor tersebut berasal dari observasi di TK Gugus II Kecamatan Berbah. Adapaun pengolahan data menghasilkan Mean sebesar 20,87; Median sebesar 22,00; Rerata Teoritik 13,5 Standar Deviasi sebesar 4,5, skor Minimum 7 dan skor Maximum 27. Selanjutnya dibuatlah tabel rumus lima kategori keterampilan sosial sebagai berikut.

Tabel 1. Rumus Lima Kategori Keterampilan Sosial

\begin{tabular}{lll}
\hline No & \multicolumn{1}{c}{ Kelompok } & \multicolumn{1}{c}{ Hasil Hitungan } \\
\hline 1. & Sangat tinggi & $\mathrm{X} \geq 21,6$ \\
\hline 2. & Tinggi & $16,2 \leq \mathrm{X}<21,6$ \\
\hline 3. & Sedang & $10,8 \leq \mathrm{X}<16,2$ \\
\hline 4. & Rendah & $5,4 \leq \mathrm{X}<10,8$ \\
\hline 5. & Sangat rendah & $\mathrm{X}<5,4$ \\
\hline
\end{tabular}

Berdasarkan hasil lima kategori keterampilan sosial yang telah dihitung, maka tingkat keterampilan sosial anak Kelompok B di Gugus II Kecamatan Berbah, Sleman dapat dihitung dengan kemudian disajikan dalam tabel distribusi kecenderungan lima kategori keterampilan sosial sebagai berikut.

Tabel 2. Distribusi Kecenderungan Lima Kategori Keterampilan Sosial

\begin{tabular}{lcc}
\hline \multicolumn{1}{c}{ Kategori } & Frekuensi & \% \\
\hline Sangat Tinggi & 49 & 53 \\
\hline Tinggi & 30 & 32 \\
\hline Sedang & 13 & 14 \\
\hline Rendah & 1 & 1 \\
\hline Sangat Rendah & 0 & 0 \\
\hline Total & 93 & 100 \\
\hline
\end{tabular}


Dari Tabel 2 tentang distribusi kecenderungan lima kategori keterampilan sosial dapat diketahui bahwa keterampilan sosial anak Kelompok B di Gugus II Kecamatan Berbah, Sleman pada kategori sangat tinggi mencakup 49 anak dengan persentasenya 53\%; kategori tinggi berjumlah 30 anak dengan persentasenya 32\%; kategori sedang berjumlah 13 anak dengan persentasenya 14\%; kategori rendah berjumlah 1 anak dengan persentasenya 1\%; dan kategori sangat rendah berjumlah 0 anak dengan persentasenya $0 \%$.

Untuk memperjelas tabel distribusi kecenderungan lima kategori keterampilan sosial dapat dijelaskan kembali pada Gambar 1.berikut.

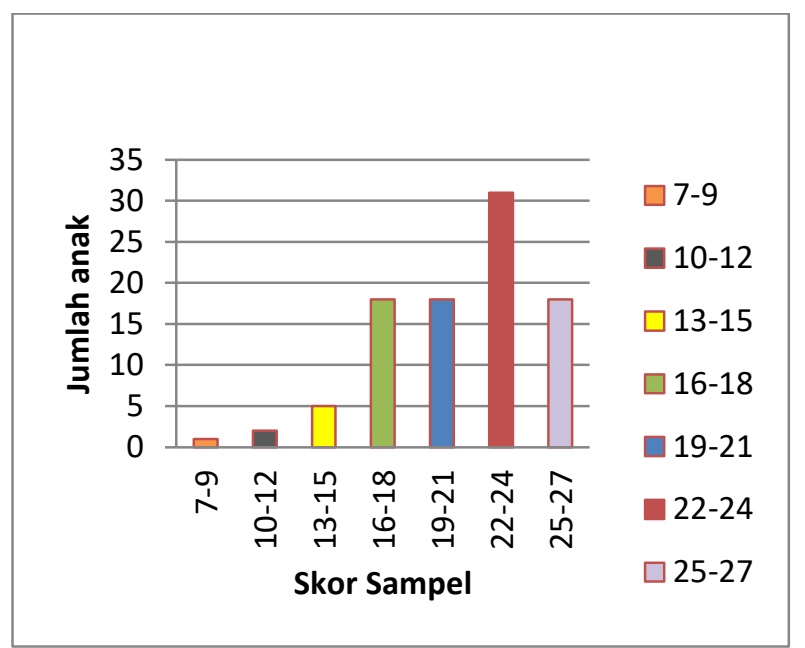

Gambar 1. Diagram Batang Tingkat Keterampilan Sosial

Berdasarkan diagram batang tersebut menunjukkan frekuensi keterampilan sosial yang paling tinggi terletak pada interval 22-24 sebanyak 31 anak, frekuensi keterampilan selanjutnya berjumlah 18 anak terdapat pada interval 16-18, 19-21, dan 25-27. Kemudian dilanjutkan dengan yang lebih rendah dengan interval 13-15 berjumlah 5 anak, dan yang lebih rendah selanjutnya memiliki frekuensi 2 anak dengan interval 10-12 serta yang paling rendah terletak pada 7-9 sebanyak 1 anak Selanjutnya persentase keterampilan sosial dapat disajikan melalui diagram lingkaran sebagai berikut.

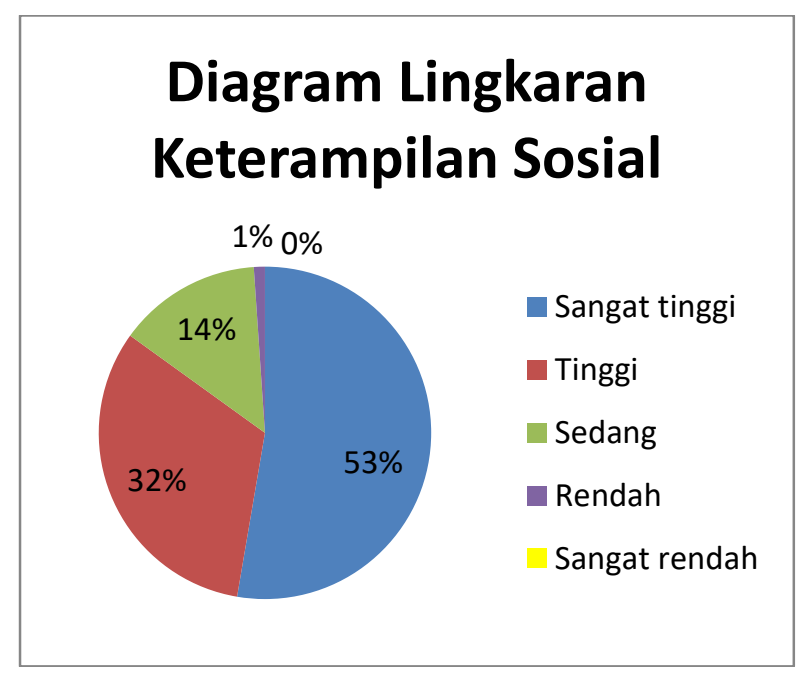

Gambar 2. Diagram Lingkaran Tingkat Keterampilan Sosial Anak

Dalam diagram lingkaran keterampilan sosial, maka dapat dilihat bahwa keterampilan sosial anak kelompok B di TK Gugus II Kecamatan Berbah pada kategori sangat rendah memiliki kedudukan $0 \%$. Selanjutnya pada kategori rendah memiliki persentase $1 \%$, kategori sedang memiliki peningkatan persentase menjadi 14\%, kategori tinggi mencapai 32\% dan kategori sangat tinggi menduduki peringkat paling atas dengan jumlah persentase yaitu 53\%. 
Berdasarkan hasil diketahui keterampilan sosial anak kelompok B di TK Gugus II Kecamatan Berbah, Sleman masuk dalam kategori sangat tinggi dengan jumlah frekuensi yang masuk adalah 49 dengan persentase 53\%. Perolehan kategori sangat tinggi tersebut karena perolehan skor anak memperoleh hasil lebih dari 22. Hal ini menunjukkan bahwa secara keseluruhan anak-anak telah memiliki keterampilan sosial yang dibutuhkan dalam kegiatan sehari-hari.

\section{Pembahasan}

Anak dapat memiliki tingkat keterampilan sosial yang tinggi mencakup keterampilan berkomunikasi yang mencakup beberapa indikator diantaranya adalah kemampuan untuk mendengarkan orang lain, komunikasi efektif, melakukan kontak mata, berbicara dengan sopan, mengenal satu sama lain, dan memberikan pujian. Kemudian pada keterampilan untuk menjadi bagian dari kelompok mencakup kemampuan anak saat bergabung dalam kelompok sosialnya. Sementara pada aspek kerja sama memiliki indikator mengikuti aturan kelas dan kerja sama dalam suatu kegiatan. Selanjutnya pada aspek kontrol diri memiliki indikator kemampuan anak untuk mengekspresikan emosinya sesuai kondisi. Pada aspek empati memiliki tiga indikator diantaranya adalah penuh pengertian, tenggang rasa dan peduli terhadap sesama. Adapun aspek yang terakhir adalah tanggung jawab yang memiliki indikator menghargai barang milik orang lain serta bertanggung jawab atas perilakunya sendiri. Hal tersebut sesuai dengan pendapat George (2012: p 254-255) bahwa anak TK terus belajar untuk mengatur emosi dan interaksi sosialnya. menambahkan bahwa, sebagian besar anak juga sangat percaya diri, ingin ikut serta, dan ingin dapat menerima tanggung jawab.

Tingkat keterampilan sosial yang tinggi menurut Elliot (1990) merupakan perilaku terpelajar yang dapat diterima secara sosial yang memungkinkan seorang individu untuk berinteraksi secara efektif dengan orang lain. Keterampilan sosial yang dimiliki oleh anak dapat bertujuan untuk menghindari interaksi sosial yang negatif. Itulah mengapa tingkat keterampilan sosial perlu di ukur untuk dapat menjadi tindak lanjut bagi keluarga dan pihak sekolah.

Perolehan keterampilan sosial yang tinggi tentunya tidak lepas dari campur tangan dari keluarga. mayoritas anak-anak yang ada di TK Gugus II Kecamatan Berbah dibesarkan dalam keluarga yang harmonis. Orang tua dapat menciptakan pola asuh yang demokratis di dalam keluarga seperti selalu mendengarkan keinginan anak, namun tetap dalam bimbingan orang tua. Orang tua juga menjalin komunikasi dengan anak setiap harinya, karena mayoritas anak masih dalam pengasuhan orang tua. Selain itu, orang tua mengajarkan untuk bergaul dengan masyarakat dengan baik, karena masih banyaknya kegiatan di wilayah Desa. Hal tersebut sesuai dengan pendapat Sumantri dan Syaodih (2010: 2.39) yang mengungkapkan bahwa orang tua sangat dianjurkan memberikan bimbingan dengan cara mengajarkan kepada anak bagaimana cara bergaul di masyarakat dengan tepat.

Tidak hanya keluarga yang memiliki peran penting dalam perolehan keterampilan sosial yang tinggi, namun sekolah juga memiliki andil. Kilic dan Aytar (2017: 185) mengungkapkan bahwa adanya pengaruh program pelatihan keterampilan sosial pada anak di sekolah. Dalam hal itu, program pelatihan keterampilan sosial di sekolah dibuktikan dengan masih memuat pembelajaran sosial dan budaya. Tidak hanya secara kognitif saja, namun kemampuan sosial emosional lebih di kedepankan di sekolah.

\section{SIMPULAN}

Berdasarkan hasil dan pembahasan maka dapat diambil kesimpulan terhadap penelitian ini, yaitu.

1. Anak Kelompok B di TK Gugus II Kecamatan Berbah, Sleman telah memiliki keterampilan sosial yang sangat tinggi dibuktikan dari data mampu mencapai skor di atas 22 dengan jumlah frekuensi 49 dan hasil persentase $53 \%$.

2. Adapun keterampilan sosial pada tingkat tinggi berjumlah 30 anak dengan persentasenya $32 \%$

3. Keterampilan sosial tingkat sedang berjumlah 13 anak dengan persentasenya 14\%; kategori rendah berjumlah 1 anak dengan persentasenya 1\%; dan kategori sangat rendah berjumlah 0 anak dengan persentasenya $0 \%$.

4. Keluarga, lingkungan dan sekolah memiliki peran penting dalam perolehan kemampuan keterampilan sosial anak yang sangat tinggi. 
Berdasarkan hasil penelitian, pembahasan dan kesimpulan yang telah diuraikan di atas, maka penulis mengajukan saran agar keterampilan sosial anak dapat seluruhnya berkembang secara optimal pada semua anak dengan cara sebagai berikut.

1. Bagi Guru, dapat menindaklanjuti hasil penelitian keterampilan sosial yang belum berkembang pada anak untuk dapat diberikan intervensi. Adapaun keterampilan sosial yang belum berkembang dengan baik adalah kemampuan untuk memuji hasil karya teman. Guru dapat memberikan pembiasaan pemberian apresiasi terhadap semua siswa.

2. Bagi Kepala Sekolah, perlunya untuk memberi kebijakan agar sekolah dapat menindaklanjuti hasil penelitian mengenai keterampilan sosial agar keterampilan sosial lebih meningkat dan optimal pada keseluruhan anak. Selain itu, memfalitasi kegiatan pembelajaran anak yang dapat berhubungan dengan keterampilan sosial.

\section{UCAPAN TERIMA KASIH}

Peneliti mengucapkan terima kasih kepada berbagai pihak yaitu para dosen di jurusan PAUD, para subjek penelitian, dan pihak lainnya yang telah memberikan dukungan dan dorongan sampai terselesaikannya penelitian ini.

\section{DAFTAR PUSTAKA}

Ambrose, H. (2013). Young children's emotion regulation and social skills: the role of maternal emotional socialization and mother-child interactional synchrony. Diakses pada tanggal 11 Februari 2019 dari https://core.ac.uk/download/pdf/72774695.pdf.

Arslan, E., Saltali, N.D \& Yilmaz, H. (2011). Social skills and emotional and behavioral traits of preschool children. Social Behavior and Personality An International Journal, 39 (9), 12811288.

Ayouby. (2017). Dampak penggunaan gadget pada anak usia dini. Diakses pada tanggal 26 April 2019 dari

https://www.google.com/url?sa=t\&source=web\&rct=j\&url=http://digilib.unila.ac.id/27131/3/S KRIPSI\%2520TANPA\%2520BAB\%2520PEMBAHASAN.pdf.

Azwar, S. (2016). Metode penelitian. Yogyakarta: Pustaka Pelajar.

Eleby, C. (2009). The impact of a student's lack of social skills on their academic skills in high school. Diakses pada tanggal 20 Februari 2019 dari https://files.eric.ed.gov/fulltext/ED529283.pdf

Elliot, S.N. (1990). Social skills development social skills development in early childhood in early childhood enabling learning, growing friends. Diakses pada tanggal 11 Februari 2019 dari www. images.pearsonassessments.com/...lec_socialskills_elliott.pdf.

George,S.M. (2012). Dasar-dasar pendidikan anak usia dini. (Terjemahan Suci Romadhona dan Apri Widiastuti) Jakarta: Indeks.

Hurlock, E.B. (2011). Psikologi perkembangan suatu pendekatan sepanjang rentang kehidupan. (Terjemahan Istiwidayanti). Jakarta: Erlangga

Izzaty, R.E, Setiawati, F.A. \& Ayriza, Y. (2017). Pengembangan buku program pembelajaran keterampilan sosial bagi guru taman kanak-kanak. Jurnal Peneletian Ilmu Pendidikan, 10 (1), 3-39. 
Jurnal Pendidikan Anak, Volume 9 (2), Tahun 2020

Yuana Resmasari

Kilic, K.M \& Aytar, F.A.G. (2017). The effect of social skills training on social skills in early childhood, the relationship between social skills and temperament. Journal Faculty of Education. 42 (191). 185.

Lynch, S.A \& Simpson, C.G. (2010). Social skills: laying the foundation for success. Dimensions of Early Childhood. 38 (2) 3.

Olcer, S.A \& Aytar, A. (2014). A comparative study into social skills of five-six year old children and parental behaviors. Procedia-Social, Behavior, Sci,14, 976-99.

Presiden. (2003). Undang-Undang RI Nomor 20, Tahun 2003, tentang Sistem Pendidikan Nasional.

Reid, K., Littlefield, L \& Hammond. (2008). Early intervention for preschoolers with behaviour problems: preliminary findings for the exploring together preschool program. Australian eJournal for the Advancement of Mental Health, 7(1), 1-2.

Sudjana, N. (1997). Penilaian hasil proses belajar mengajar. Bandung: Remaja Rosdakarya.

Sugiyono. (2015). Metode penelitian pendidikan. Bandung: Alfabeta.

Sumantri, M. \& Syaodih, N (2010). Perkembangan peserta didik. Jakarta: Universitas Terbuka.

Thalib, S,B. (2010). Psikologi pendidikan berbasis analisis empiris aplikatif. Jakarta: Kencana Media Group. 